\title{
Resume af etårsplanen for 1971
}


Med det formål at informere hele folket og dermed sikre dets permanente deltagelse i styret overgiver Folkefrontsregeringen denne fremstilling af ODEPLAN for det nationale Udviklingsråd til offentlig diskussion. Dette dokument ligger inden for rammerne af, hvad der tidligere er offentliggjort i dokumenter fra regeringen, som f.eks. dekreterne om den offentlige ejendom og den $\varnothing$ konomiske politik, og ligger, helt fundamentalt, inden for rammerne af Folkefrontens program. Dette papir har til hensigt at vise, hvilke planer regeringen og det chilenske folk må løse i året 1971 på vejen frem gennem transformation og udvikling.

Hermed startes en række diskussioner på nationalt plan, og disse vil blive fuldstændiggjort af mere detaljerede diskussioner, som snarest vil blive etableret gennem udleveringen af regionalplanerne til hvert af de regionale udviklingsråd, som regeringen netop har dannet.

Arbejdere, arbejdsgivere, ungdommen, de liberale erhverv og alle sektorer i landet indbydes til at diskutere de ideer og forslag, der er indeholdt i dette dokument, og til at lade deres bemærkninger, kritik, forslag, o.s.v. tilflyde de involverede myndigheder, for at de kan blive indarbejdet i den endelige version af planen og i den praktiske ledelse af den chilenske $\varnothing$ konomi.

\section{Generelle målsatninger for 1971-planen}

Den $\varnothing$ konomiske politik for året 1971 sigter på samtidig at angribe en række problemer, som i årevis har berørt størstedelen af befolkningen, og på at begynde en udvikling med dybtgående strukturelle ændringer, som kan sikre en vedvarende løsning på det chilenske samfunds grundlæggende problemer gennem en omdannelse af vor $\varnothing$ konomi i retning af en begyndende socialistisk struktur.

Den chilenske $\varnothing$ konomi har i de sidste år vist klare tegn på stilstand, og det kom til en kritisk kulmination i 1970 inden valgkampens begyndelse. I de sidste år er produktionen pr. indbygger næsten ikke steget, i 1967 var der ingen for$\emptyset$ gelse, og i de år, hvor der har været en stigning, har den været i størrelsesordenen 1 pct., og tiåret er endt i stagnation. På samme tid udviser arbejdsløsheden i denne periode en stigning. Ligeledes er inflationen skærpet, og i 1970 kulminerede den med en stigning på 34,9 pct. i forbrugerpriserne. I nævnte tidsrum har man også set en forværring af den ulige indkomstfordeling, særligt hos de ufaglærte arbejdere.

Disse svære problemer har været gennemgående træk i økonomien i de sidste årtier. Dette er det nødvendige resultat af vort lands $\varnothing$ konomiske og sociale struktur, hvis primære træk, som det gentagne gange er påpeget, er en høj grad af koncentration af ejendomsretten til produktionsmidlerne i alle de $\varnothing$ konomi- 
ske sektorer (storbrug, industri- og bankmonopoler, o.s.v.), og som konsekvens heraf en høj grad af indkomstkoncentration. Ydermere finder man stærke internationale afhængighedsrelationer og en stigende de-nationalisering af den chilenske økonomi og en åben eller skjult udnyttelse af statsapparatet fra monopolernes side.

1971-planen er grundlæggende baseret på i årets løb at opnå en kraftig forøgelse af produktionen, hvilket er nødvendigt for afgørende at formindske arbejdsløsheden; ligeledes at opnå en grundlæggende omfordeling af indkomsten; at opnå løsningen på akutte behov inden for boligområdet, sundhedsvæsnet, undervisningen o.s.v.; samt at påbegynde og fastholde den økonomiske genaktiviserings resultater, idet de vil tillade en hurtig og vedvarende udviklingsproces. De nævnte målsætningers opfyldelse hænger uløseligt sammen med en bremsning af inflationen, en ting som den siddende regering har givet høj prioritet på grund af dens følgevirkninger i resten af den skitserede $\varnothing$ konomiske politik.

En afgørende betingelse for at opnå de nævnte målsætninger er den øjeblikkelige påbegyndelse af strukturelle ændringer som nationalisering af de store kobber- og jernminer og statslig kontrol med produktionen af kul, salpeter, nationalisering af banksystemet, indlemmelser af de store industrielle og handelsmæssige monopoler i den offentlige ejendom, en hurtigere og mere effektiv landboreform og en udvidelse af statens andel i udenrigshandlen. Det er gennem disse grundlæggende ændringer, at staten vil kunne disponere over effektive midler til at sikre omfordeling af indkomsten, til at stimulere og dirigere produktionen og til at fastholde virkningerne og dirigere dem med en række planlagte endemål for den sociale og økonomiske udvikling. På alle disse områder er det nødvendigt at skabe folkets effektive deltagelse i kontrollen og dirigeringen af de $\varnothing$ konomiske aktiviteter lige fra planernes formulering til deres praktiske anvendelse.

Man modtog den chilenske $\emptyset$ konomi i en tilstand, som siden hen er blevet forværret på grund af modstand fra storbrugere og monopoler, og den direkte genopbygningsfremgangsmåde er udtrykt i programmerne for $\varnothing$ konomisk aktivisering, hvis primære dele er:

H Programmet for boligsektoren: en ekstraordinær anstrengelse for at løse de presserende problemer i forbindelse med installeringen af sanitære anlæg i 124.000 boliger samt påbegyndelsen af mere end 83.000 boliger.

is Hospitals- og skolebyggeri, som væsentligt vil øge disse sektorers kapacitet, efter de endelige og detaljerede regionalplaner.

is Programmet for offentlige arbejder, hvis væsentligste indhold er de arbejder, der er til umiddelbar social fordel, og som hurtigst vil kunne give et produktivt 
afkast (kloakering, drikkevandsforsyning, mindre kunstvandingsprojekter), og ligeledes en forbedring af det interne havnesystem.

Programmet for byggeriet betyder en udvidelse af de offentlige udgifter i forhold til 1970 med mere end 3 milliarder escudos (ca. 780 millioner kr.), hvilket vil få betydningsfulde følger både direkte og indirekte for de $\varnothing$ vrige sektorer. Det er særligt nødvendigt at påpege virkningen heraf som en opsugningsmekanisme af arbejdsløsheden; det betyder i byggesektoren en fuldstændig opsugning af den arbejdskraft, som findes.

is Landboreformprogrammet, der væsentligst består af en fremskyndelse af eksproprieringen af storbrugene, således at der i 1971 vil blive eksproprieret 1000, og således at processen fuldføres i de næstfølgende år.

论 Programmet til fremme af eksporten, der er baseret på skabelsen af en statslig, kommerciel kapital og på åbningen af nye markeder.

is Programmet til udvidelse af industri og statslig investering, hvis vigtigste reguleringsmekanisme er produktionsoverenskomsterne.

Statsmagtens indirekte indgriben består af en række politisk- økonomiske forholdsregler, der vil sikre en udvidelse af produktionen, hvilket der er objektive betingelser for i den store margen af ubenyttet produktionskapacitet og uudnyttet arbejdskraft. De skitserede fremgangsmåder vil betyde en stimulering af produktionen i det pågældende tidsrum.

De vigtigste mekanismer i produktionsforøgelsen er en demokratisering og en adgang til billig kredit, som også når ud til små og mellemstore producenter; en fastfrysning af visse vigtige udgiftsposter ved hjælp af forsyning med råstoffer, der er produceret af statsejede foretagender (stål, energi, brændsel, transport, etc.); stabilisering af priser på importerede råstoffer ved hjælp af en opretholdelse af vekselkursen; oprettelsen af en statslig indkøbskapital; o.s.v.

Det, der kendetegner brugen af de politisk- $\varnothing$ konomiske virkemidler, er et fors $\varnothing \mathrm{g}$ på at stimulere produktionen af varer til det offentlige forbrug samt en klar favorisering af de ikke-monopoliserede fabrikanter, især de mellemstore og små, og en stærk kontrol med de store monopoliserede foretagender. Dette er de grundlæggende træk i den økonomiske politik.

\section{Udviklingsplanerne for de enkelte sektorer}

Planerne for sektorerne er rettet mod en produktionsaktivisering, en udvidelse af infrastrukturen, en forøgelse af de offentlige tjenesteydelser og en rettelse af manglerne i handels- og finansieringsprocessen. 


\section{Planerne for produktionssektorerne}

Produktionen er steget utilfredsstillende i de senere år. Landbrugets stilstand efter 1967, den overskydende arbejdskraft, der skabes ved naturlig tilvækst, har måttet kanaliseres ind i de uproduktive sektorer, især i tjenesteydelserne.

Produktionsplanerne for 1971 er beregnede på en afhjælpning af denne misdannelse gennem en ekspansion af produktionen i landbrug, kvægavl, minedrift og industri.

\section{a. Planen for landbrug og kvagavl.}

Landbrug og kvægavl udgør ca. 10 pct. af nationalproduktet og denne sektors produktionsniveau har udvist kraftige svingninger i de sidste år; medens man i 1966 og 1967 havde en produktionsforøgelse på 7 pct. pro anno, havde man i 1968 og 1969 en formindskelse på grund af den tørke, der ramte landet i disse år, men 1970 og 1971 synes at vise muligheder for at genvinde det tabte på trods af besværlighederne for kvægavlen i 1970. I 1971 nyder man godt af den kendsgerning, at regnmængden i 1970 var normal.

Landboreformprogrammet omfatter ekspropriering af mindst 1000 storbrug, hvilket vil kunne komme 30.000 familier til gode. Dette er begyndelsen til en seksårsplan, hvis mål er eksproprieringen af 3.800 brug med et areal på 7 millioner hektarer kombineret med et etableringsprogram for mindst 70.000 familier i perioden 1971-76. Landboreformen vil blive gennemført inden for lovens rammer, og den vil opsuge en del arbejdsløse, tillade en rationel mekanisering af landbruget, rationalisere brugene og intensivere produktionen, udvikle landbrugsindustrien, skabe en bedre infrastruktur i kunstvandingen og forbedre det teknologiske niveau i landarbejdet. Et andet element i landboreformprogrammet er udstyring af de allerede etablerede brug for at forberede disse til produktionsplanen for 1971-72.

Med hensyn til produktionsprogrammerne kan det påpeges, at i småbrugene vil der ske en produktionsforøgelse i lighed med den forøgelse, man i 1970 kunne iagttage i de tilsåede områder. Med hensyn til resten af landbruget viser de tilgængelige fortilfælde, at de planlagt tilsåede arealer i 1970 forøgedes med 4 pct.; hvis den registrerede hensigt opfyldtes blot 90 pct., vil produktionen inden for landbrug og kvægavl kunne forøges med 5,3 pct. i perioden 1970-71 i forhold til 1969-70. Man bør her fastslå, at visse producenters sabotage og problemerne med den offentlige orden kan forstyrre opnåelsen af disse resultater. I hvert fald er de vanskeligheder, der kan fremkomme inden for landbruget i 1971 langt fra dem, der opstod i 1969, da produktionen nåede sin nederste grænse i det årti, og nationen viste, at den kunne overvinde problemerne ved den lave produktion. 
Hvad angår kreditter og teknisk assistance, vil man yde en kraftig støtte til landmændene ved hjælp af det nationale banksystem og organer for teknisk hjælp som INDAP og SAG. I nogle kritiske områder som Cautín vil INDAP fordoble antallet af klienter, der hjælpes med kreditter, råmaterialer, o.s.v., således at man på landsplan når op på 12.000 landmænd, der modtager hjælp, en fordobling af 1970-niveauet.

Fra og med 1971 vil man lægge stor vægt på udviklingen af landbrugsindustrien ved at opbygge vertikalt fungerende foretagender til bearbejdning af frugt, grønsager, kød, korn og andre produkter. Disse foretagender vil købe ind efter på forhånd etablerede overenskomster med landmændene, forarbejde produkterne og sælge dem på detailniveau.

Eksportprogrammet for landbrugsartikler omfatter produkter som frugt, grønsager, kød og korn for en sum på ca. 35 millioner dollars. (Ca. 233 millioner kr.). Modsat omfatter importprogrammet for 1971 hvede, majs, kødprodukter, spiseolie i tilstrækkeligt omfang til at dække den efterspørgsel, der vil fremkomme gennem en omfordeling af indkomsten.

Kunstvandingsprogrammet omfatter kanalisering af 3 store floder samt inddæmning af 8 mindre og 2 store kunstige søer.

\section{b. Planen for fiskeriet.}

Regeringen vil lægge stor vægt på at styrke fiskeriet i 1971. Man vil oprette et fiskeriministerium for at styrke aktiviteterne og til at organisere transportog havnesystemet. Man vil påbegynde opbygningen af mindst 4 fiskerihavne, nogle af disse med fryseanlæg. Ligeledes vil man igangsætte et program til fornyelse af fiskeriflåden, hvilket omfatter projekter som udbygning af ansjosog tunfiskerflåden, trawlerflåden o.s.v. Programmet for terminaler og distribution omfatter projekter som fryseterminalen i Concepción, Valparaíso samt udvidelsen af Santiago og udvidelsen af veje og bestanden af transportmateriel.

\section{c. Planen for minedrift.}

Denne sektor vil gennemgå vidtrækkende ændringer i 1971 som følge af nationaliseringen af minerne. Programmets generelle mål er at fuldføre statskontrollen med kobber, jern og salpeter.

Med hensyn til kobberet har den befuldmægtigede til Nationalkongressen sendt en plan for en konstitutionel reform, som vil tillade nationalisering af de store kobberminer. Denne plan er et vigtigt skridt i generobringen af landets rigdomme, eftersom 80 pct. af kobberproduktionen indtil slutningen af 1970 var kontrolleret af udenlandske foretagender på trods af de undertegnede overenskomster med den tidligere centraladministration.

Med hensyn til jernet fastsætter 1971-planen, at jernlejerne i El Tofo og Romeral, som siden 1951 har været i hænderne på Bethlehem Chile Iron Mi- 
nes Company, skal overgå til den chilenske stat. Planen påtænker at integrere Companía de Acero del Pacífico (CAP) i den offentlige ejendom, og den omfatter ligeledes nationalisering af minekompagniet Lofa Schwager, der tidligere har været på private hænder.

I løbet af 1971 vil man opfylde programmet for udvidelse af minedriften, hvilket vil medføre, at man når en produktion på ca. 940.000 tons. Det Nationale Minedirektorat vil blive pålagt at reducere den instabilitet, der ofte er til gene for de små og mellemstore kobberproducenter ved at sikre et stabilt prisleje og regelmæssig teknisk og finansiel støtte. Hvad angår forhandlingen af kobberet, omfatter planen, at den chilenske stat indlemmes i eksporten af dette metal, hvilket vil sikre landets muligheder for at finde de bedste eksportmarkeder inklusive de socialistiske lande. En anden betydningsfuld plan omfatter udviklingen af de tekniske og videnskabelige unders $\emptyset$ gelsesmetoder med hensyn til mineralsøgning, -optagning og -forarbejdning for at reducere den teknologiske afhængighed af udlandet.

Regeringen har undertegnet en overenskomst med salpeterarbejderne, og man har fastlagt at $\varnothing \mathrm{ge}$ produktionen fra ca. 650.000 tons til 1 million tons i 1971. Med jernet har man sat sig det mål at nå en produktion på 12 millioner tons, og samtidig indleder man et ambitiøst investeringsprogram for at igangsætte Boguerón Chauar-minen og udvide installationerne i Algarrobo og Guacolda. Disse investeringer er begyndelsen til en udvidelse af stålproduktionen.

Kulproduktionsplanen påtænker en produktionsforøgelse fra 1,5 millioner tons i 1970 til ca. 1,6 millioner tons i 1971, hvilket svarer til en 8 pct.'s forøgelse.

\section{d. Planen for industrisektoren.}

Man vil dække efterspørgslen efter industriprodukter i 1971 ved at aktivisere den ikke-udnyttede produktionskapacitet samt ved generelle kapacitetsudvidelser. Gennem a) en omfordeling af indkomsten, b) en udvidelse af byggeriet, og c) oprettelse af statsforetagender vil man øge efterspørgslen og dække denne gennem bl.a. en $\emptyset$ get import af råstoffer.

Staten vil gennem sine investeringer færdiggøre allerede igangværende projekter og påbegynde nye. De første resultater, der vil kunne ses i 1971, er: frugtforarbejdningsfabrikkerne i Aconcagna og O'Higgens, en saltfabrik, en plov- og harvefabrik, en fabrik for kasseapparater, o.s.v. Disse fabrikker vil bidrage væsentligt til produktionsfor $\varnothing$ gelsen. Saltfabrikken vil producere 6.000 tons om året, plov- og harvefabrikken kan fremstille 1.200 plove og 1.200 harve pr. år, og markedet for denne produktion vil blive fordoblet eller tredoblet ved hjælp af landboreformen, der bl.a. omfatter udlevering af større landbrugsredskaber. 
Af andre vigtige investeringsprojekter kan nævnes produktionen af råstål og stålbarrer, som skal bringes op fra 600.000 til én million tons inden 1972; IANSAfabrikken, som vil få en kapacitet på 60.000 tons pr. år, og cellulosefabrikken i Constitución, som vil kunne producere 175.000 tons kraft-celluose.

Regeringens politik sigter i stigende grad på at kunne forsyne befolkningen med vigtige produkter. Dette kan ses af de vedtagne projekter i næringsmiddelog tekstilindustrien: fryseanlægget i Valparaíso, som vil få en kapacitet på 200.000 kasser æbler; slagteriet i Castro, som vil få en årlig kapacitet på 3.000 tons oksekød, 170 tons fårekød og 170 tons svinekød. Den samlede sum, regeringen i 1971 vil investere i næringsmiddelindustrien, andrager 11,9 millioner dollars (ca. 77 millioner kr.), hvilket er 21 pct. af de samlede investeringer i industrien.

Blandt de projekter, der sættes igang i 1971, er de vigtigste: en acetylalkoholfabrik, en natriumsulfat-fabrik, en natriumsilikat-fabrik, en alkyl-benzen-fabrik, o.s.v. Mere betydningsfuldt er det, at disse produkter er omfattet af integrationsprogrammet i ALALC (Det latinamerikanske Fællesmarked og det første fors $\emptyset \mathrm{g}$ på at skabe økonomisk integration i Latinamerika) og i El Pacto Andino (Andeslandenes fælles $\varnothing$ konomisk- og forsvarspolitisk traktat). Cementfabrikken i Antofagasta spiller en vigtig rolle i regeringens boligprogram, o.s.v. Alt i alt har man for 1971 fremstillet 126 nye projekter, og man vil udvide for 87,8 millioner dollars (ca. 610 millioner kr.).

Man må her påpege, at industrien har meget stor betydning som arbejdsskabende faktor, idet en generel aktivisering i denne sektor vil kunne opsuge store mængder af arbejdskraft.

\section{Planerne for de infrastrukturelle faktorer}

Opmuntring af produktionssektorerne vil blive fulgt af udvidelser i den $\varnothing$ konomiske infrastruktur, d.v.s. energi, brændstof, transport og kommunikation.

\section{a. Planen for energisektoren.}

Planen omfatter en udvidelse af energiforsyningen med 15,3 pct. i forhold til 1970. Det er værd at bemærke, at $2 / 3$ af energiproduktionen er hydroelektrisk, mens $1 / 3$ er termoelektrisk. Denne sidste trediedel forbruger 755.000 tons kul pr. år, og man sigter efter at nedskære den ved at investere adskillige millioner dollars i hydroelektriske anlæg.

Med hensyn til olie omfatter planen raffinering af 6,1 millioner $\mathrm{m}^{3}$ råolie, hvoraf landet selv kan levere 2 millioner, mens resten importeres. Der vil blive fremstillet 27.000 tons flydende gas. For 1971 er det planlagt, at ENAP direkte skal distribuere alt ætylen, 17,6 pct. af dieselolien og 68,3 pct. af de $\varnothing$ vrige brændstoffer. 
Resten af produkterne distribueres af private selskaber eller gennem direkte import til f.eks. kobberfabrikkerne. ENAP's mål er, forsåvidt angår olieprodukter, at forsøge at dække det nationale forbrug og så vidt muligt eksportere. I 1971 vil fabrikken i Poesión begynde produktionen, og dette vil muliggøre en eksport på 220.000 tons nedkølet, flydende gas.

For fremtidig at kunne udvide olieproduktionen har regeringen undertegnet en overenskomst med FN's udviklingsråd for at få unders $\varnothing$ gt det undersøiske plateau i Magellan-strædet og andre lovende arealer.

\section{b. Planen for transportsektoren.}

Transportsektoren er fundamentalt afhængig af produktionsniveauet i de $\varnothing$ vrige $\varnothing$ konomiske sektorer. I konsekvens heraf vil transportydelsernes mængde i 1971 stige i takt med den $\varnothing$ konomiske udvidelse. For at kunne leve op til dette har man skitseret en plan for større koordination mellem de forskellige transportmidler og for en mere intensiv og rationel brug af den eksisterende infrastruktur og det eksisterende udstyr.

Inden for jernbanerne er det særlig passagertransporten i den sydlige del af landet, der spiller en rolle, og her påtænker man en udvidelse i størrelsesordenen 4 pct. Med hensyn til godstransporten forudser man en stigning på mindst 5 pct. i forhold til 1970, men systemet kan bære en stigning på helt op til 30 pct.

For at kunne opfylde programmet må statsbanerne investere ca. 330 millioner escudos (eller ca. 86 millioner kr.), hvoraf de vigtigste poster er en fornyelse af materiellet ( 700 vogne af overvejende nationalt fabrikat samt 6 lokomotiver) og en forbedring af spornettet.

Man påtænker i 1971 at udvide den urbane transportservice væsentligt, hvilket vil betyde en forøgelse i antallet af passagerer på fra 88 pct. i Santiago, 73 pct. i Valparaíso, 53 pct. i Concepción til 15 pct. i Antofagasta. Til dette formål regner man med at indsætte 420 nye busser samt istandsætte den bestående bus- og trolleybuspark.

Den private lastbiltransport vil antagelig kræve 200 nye køretøjer, og dette betyder en investering på 36,4 millioner escudos (eller ca. 9,4 millioner kr.).

For luftfartens vedkommende er der planlagt et investeringsprogram til fornyelse af den nationale og internationale luftflåde. Budgettet for 1971 indeholder bl.a. anskaffelse af en Boeing 707 til 8,5 millioner dollars for at styrke de eksisterende internationale ruter og for at udvide dem til Europa og Cuba; køb af en Boeing 727 transportmaskine til 4,4 millioner dollars, som skal varetage ruten Santiago-Punta Arenas; udskiftning af de DC-3'ere, der betjener Chiloé og Aysén, med to mindre maskiner til 20 personer og 2 tons last, til at begynde med.

Med hensyn til skibstransporten er der planlagt offentlige investeringer på 5,5 millioner dollars i 6 slæbebåde på 6.000 tons dødvægt hver samt 2 havgående 
slæbere til kultransport. Men vil påbegynde ombygning og mekanisering af flere af de vigtigste havne: Valparaíso, Puerto Montt, Arica, o.s.v.

For de $\varnothing$ vrige transportvejes vedkommende er der udarbejdet et bredt program, som sigter på en fortsat udbygning af landeveje og autostradaer. Man vil indlede en del nykonstruktioner samt modernisere nogle tunneler, udbygge og forbedre 3 lufthavne, o.s.v.

\section{Planerne for socialsektoren}

Disse planer er rettet mod en forbedring af boligerne, bedre undervisningstilbud og bedre sundhedsvæsen samt bedre betingelser for turismen.

\section{a. Planen for boligsektoren.}

Boligplanen for den offentlige sektor i 1971 omfatter bygning af 83.112 boliger mer et samlet areal på 3.500.000 m². Dette er fordelt på 68.088 étplansboliger med et samlet areal på $2.650 .000 \mathrm{~m}^{2}$ og 15.024 etageboliger med et areal på $850.000 \mathrm{~m}^{2}$. Inden 31 . december 1971 skulle man altså kunne færdiggøre ca. 80.000 boliger, hvilket vil kunne løse boligproblemerne for 400.000 mennesker. De byggemodningsarbejder, man vil udføre, skulle kunne komme 135.000 boliger til gode. Der vil blive opkøbt ca. 1.600 hektarer jord, og da man i forvejen råder over 2.700 hektarer, vil man altså få 4.300 hektarer til bebyggelse. Dette er tilstrækkeligt til at gennemføre planerne, da disse omfatter et areal på 2.508 hektarer. Af de 68.088 planlagte boliger vil de 35.482 blive bygget på traditionel vis, mens de resterende 32.606 vil være industrialiseret byggeri.

Programmet for det nationale opsparings- og udlånssystem omfatter 14.500 udlån, hvoraf 50 pct. er beregnet på køb af allerede byggede boliger, mens de øvrige 50 pct. er lån til opførelse af nye boliger.

Den planlagte investering i boliger i 1971 er på 4.805 millioner escudos (ca. 1.250 millioner kr.), en fordobling fra det foregående år. Denne forøgelse fremkommer ved, at der i den offentlige sektors budget er sket en forøgelse på 176,9 pct., mens investeringerne i den private sektor viser en stigning på 15,1 pct. Boligbyggeriet er koncentreret til provinserne Santiago, Concepción og Valparaíso, primært på grund af beskæftigelsesmulighederne. Med hensyn til arbejdsløsheden i 1971 kan man forudse, at den arbejdsløshed på 22 pct., man så i 1970 inden for denne sektor, praktisk taget skulle kunne opsuges af den stigende produktion.

Man regner med, at materiale-forbruget i byggesektoren f.eks. med hensyn til cement ikke vil være stort nok til at udligne produktionen i landets tre cementfabrikker, dersom disse udnytter kapaciteten fuldt ud, men som produktionen er i øjeblikket, er den dækkende for forbruget. 


\section{b. Planen for det offentlige sundhedsvasen.}

Planen for 1971 omfatter en udvidelse af ernæringsprogrammet, en rationalisering af sektorens service og en udvidelse af hospitalsbyggeriet. Den omfatter ligeledes en forøgelse af ernæringstilskudene, således at udleveringen af mælk firedobles i forhold til 1970, hvilket vil sige, at der vil blive udleveret 48 millioner kilo mælk til en pris af ca. 385 millioner escudos (ca. 100 millioner kr.).

Man har planlagt ekstraordinære kampagner inden for følgende områder:

1. Mavelidelser hos børn: større antal indlæggelser, flere konsultationsmuligheder og sygebesøg hos børn, bedre sanitær kontrol og undervisning.

2. Nødstilfælde i vinterperioden: en forøgelse af antallet af specielle vaccinationer, større antal hospitalsindlæggelser og børnekonsultationer samt øget undervisning i forbindelse hermed.

3. Alkoholisme: en forøgelse af præventionen og den hermed forbundne undervisning og i nogle tilfælde revalideringshjælp til alkoholikere.

4. Sanering og miljøbeskyttelse: herunder en koordinering af de sektorer, der arbejder med problemerne, især byrådene og ministeriet for sundhedsvæsen og den militære arbejdstjeneste, med aktiv deltagelse af de organiserede arbejdere. Dette program omfatter organisering af et Renovationskompagni i Santiago, og der vil blive lagt vægt på etablering af drikkevandsservice både på landet og i byerne.

Blandt de vigtigste ændringer, der i 1971 vil ske i sundhedssektoren, er en demokratiseringsplan for SNS (sundhedsstyrelsen). Den plan vil tillade en indlemmelse af såvel akademisk som administrativt og andet personel på alle niveauer i SNS, også forbrugerne vil kunne få indflydelse gennem deres offentlige organisationer: CUT (fagforening), Junta de Vecinos og Centro de Badres, idet alle vil få besluttende myndighed. Repræsentationen bliver proportional og vil kunne forhindre bureaukratiske metoder, interne konflikter og andre vanskeligheder, der måtte kunne besvære SNS's funktioner. Demokratiseringen vil finde sted på hospitalsniveau, på konsultationsniveau og på internt hospitalsniveau, såvel som på de overordnede regionale og nationale organisationers niveau.

Af de umiddelbart virkende forholdsregler i regeringsprogrammet til fremme af borgernes mulighed for hjælp fra sundhedsvæsenet kan nævnes en eliminering af de bureaukratiske besværligheder, gratis adgang til medikamenter og hospitalsundersøgelser samt lægekonsultationers integrering i de lokale bebyggelser. Generelt vil disse forholdsregler være til gavn for de laveste indkomster.

I hospitalsbyggeri-programmet er påtænkt opført 4.000 sengepladser samt påbegyndt 7 nye hospitaler, 3 konsultationscentre, 9 ombygningsprojekter og 15 landkonsultationer. 


\section{c. Planen for undervisningsvasenet.}

Følgende mål er sat for undervisningsvæsenet i 1971: a) En udvidelse af undervisningen på børnehaveniveau; b) opsugning og fastholdelse af de elever, der er i skolealderen, hvor dette måtte være påkrævet; c) udbygning af den videregående undervisning som forberedelse til teknisk-akademiske uddannelser, særligt de industrielt og landbrugsmæssigt orienterede; d) ekspansion af universitetsundervisningen gennem en udvidelse af støtten til de første-årsstuderende for at opnå en høj undervisningsdeltagelse blandt disse elever, der skal aflægge den akademiske egnethedsprøve.

Skoleundervisningen vil i 1971 omfatte 2.570 .700 børn, hvilket er en for$\varnothing$ gelse på 6,2 pct. i forhold til de i 1970 indtegnede. Det nævnte antal børn udgør 72,5 pct. af befolkningsgruppen mellem 5 og 19 år. Med hensyn til børnehaveundervisningen vil den komme til at omfatte 74.800 børn, hvilket er en forøgelse på 18,2 pct. i forhold til 1970. Antallet svarer til 28 pct. af befolkningsgruppen på 5 år. Grundskoleundervisningen vil omfatte 2.135.100 børn, en forøgelse på 3,4 pct., hvilket svarer til 70.600 børn, og totaltallet svarer til 95,1 pct. af befolkningsgruppen mellem 6 og 14 år, hvilket er en forøgelse i forhold til 1970.

Regeringen vil opfylde sit løfte om at foranstalte uddeling af gratis morgenmad til alle elever i grundskolen, og ligeledes vil man tilbyde et stort antal elever $(35,6$ pct. i 1971) gratis frokost, man vil øge adgangen til at få legater samt uddele et større antal gratis skoleuniformer.

Den videregående undervisning vil i 1971 omfatte 360.800 elever fordelt med $223.100 \mathrm{i}$ den naturvidenskabelige og den humanistiske gren og $137.700 \mathrm{i}$ den tekniske gren. Handelsskolerne vil få 278.200 elever, og den private sektor vil herved komme til at forestå undervisningen for 22,9 pct. af eleverne i den videregående undervisning. Det samlede antal elever svarer til 34,7 pct. af befolkningsgruppen mellem 15 og 19 år, hvilket ligeledes er en stigning i forhold til 1970.

Den naturvidenskabelige og den humanistiske gruppe udgør 61,8 pct. af eleverne i den videregående undervisning, mens den tekniske gruppe kun udgør 38,2 pct. I 1971 vil man lægge vægt på at udvide den tekniske undervisning, således at den industrielt orienterede retning udvides med 63 pct., mens landbrugsretningens elevtal fordobles.

På universitetsniveau vil man anstrenge sig for at udvide så kraftigt som overhovedet muligt. Man vil forøge antallet af førsteårslegater til 35.143, en forøgelse på 13.351 eller 62,8 pct. i forhold til 1970. Dette svarer til, at man optager 66 pct. af de elever, der går op til den akademiske egnethedsprøve. Den stærkeste vækst vil være at finde på Statens Tekniske Universitet, der vil øges fra 3.570 til 11.290, og ved universitetet i Concepción, der vil øges fra 1.717 til 2.990 . 


\section{d. Planen for turismen.}

Uden at underkende den traditionelle turismes rolle som $\varnothing$ konomisk udviklende faktor er det regeringens hensigt at give en plan for folkelig turisme en speciel fortrinsret. De vigtigste projekter for 1971 er:

1. Offentlige svømmebassiner. Man vil anlægge 37 svømmebassiner fordelt over hele landet samt fremsætte forslag om yderligere 25 omkring Valparaíso. De vil kunne rumme ca. 25.000 mennesker, hvilket vil sige, at de vil blive besøgt af mere end 150.000 mennesker i sæsonen. Nogle er allerede færdiggjort og trådt i funktion.

2. Camping. De allerede eksisterende campingpladser er blevet udvidet, og deres installationer er forbedret. Man har desuden anlagt en ny plads og planlagt yderligere 5 , og flere vil følge efter.

3. Hoteller og pensioner. Her har man 9 vigtige projekter i gang: et stort, førsteklasses hotel i Valparaíso; pensioner, hytter og hoteludvidelser i Iquique; to pensioner i Arica, o.s.v.

4. Af investeringerne i forbedringer og nyanlæg af veje af betydning for turismen går 15.090.000 escudos (knap 4 millioner kr.).

5. En bred støtte til private turistprojekter som hoteller, pensioner, restauranter, o.s.v. Til dette formål er afsat mere end 35 millioner escudos (ca. 9 millioner kr.).

6. Desuden vil man anlægge nye badestrande, bjerghytter, parker, forlystelsescentre, o.s.v. Man vil restaurere historiske momenter, indrette nye lokaler til salg af kunsthåndværk, o.s.v.

\section{Restruktureringsprogram for finansieringen og handelen}

Dette program har til hensigt at korrigere manglerne ved finansieringen og handelen under hensyntagen til landets industrielle udvikling, således at kapitalstrømmen i stedet for at dirigeres mod visse forfordelte sektorer kan blive til gavn for folket.

\section{a. Planen for handelen.}

Statens deltagelse i udviklingen af handelen viser sig på tre måder:

1. I en styrkelse af de statslige foretagender, der har forbindelse med distributionen, for at koordinere og effektivisere disse funktioner og for at give foretagenderne afgørende indflydelse på markedet.

2. Regulering af nøglesektorerne i distributionsprocessen, der ikke er direkte eller indirekte underlagt staten, f.eks. gennem pris- og avancekontrol, kontrol med kreditter og budgetter, o.s.v.

I 1971 vil man søge at danne et Empresa Distribuidora Nacional (Nationalt distributionsfirma) med støtte fra La Empresa de Comercio Agrícola (statsejet 
forhandlingsfirma for landbrugsprodukter), Banco del Estado (statsbanken) samt La Corporación de Fomento de la Producción (sammenslutning til udvikling af industrien). Dette foretagende vil primært få til opgave at regulere forsyningerne af konsumvarer, især for at styrke de svageste sektorer. Det skal operere imellem producent og detailhandler for at eliminere de mellemliggende led, og med det formål at billiggøre produkterne og bringe dem frem til steder, hvor man ikke før har kunnet få dem. Det skal først og fremmest tage sig af produkter som fødevarer og tekstilvarer.

\section{b. Programmet for statens overtagelse af bankerne.}

Den største forbruger af bankkreditter i den private sektor er industrien, som den 31. december 1969 stod for 42 pct. af bankernes udlån. Herefter følger landbruget med 24 pct. og handelssektoren med 16 pct. Betragter man produktionens bruttoværdi som et mål for aktiviteterne i de forskellige sektorer, finder man ud af, at den mest forfordelte sektor er landbruget, der opnåede kreditter svarende til 19 pct. af bruttoværdien af produktionen i denne sektor. Industrien derimod opnåede kun kreditter svarende til 5 pct., og alle $\varnothing v$ vrige sektorer lå endnu lavere. Minedrift, transport og offentlige tjenesteydelser opnåede de mindste kreditter.

Med hensyn til kreditdistributionen i den private sektor er det værd at bemærke den voldsomme koncentration: 51 skyldnere $(0,4$ pct. af totalen) disponerer over 1.186 millioner escudos eller 25 pct. af bankkreditterne (svarende til ca. 305 millioner kr.). I den anden ende har 28 pct. af skyldnerne adgang til 2,6 pct. eller 120 millioner escudos (ca. 31 millioner kr.). Også regionalt er der tale om en koncentration, 68 pct. af al kredit er givet til Santiago-provinsen. Der er altså tale om en opsugning af kreditter til Santiago fra de фvrige provinser. Når man ser på fordelingen med hensyn til produktionsgren i de forskellige provinser er det overalt landbruget, der råder over mere end 50 pct. af provinsbankkreditterne. I Santiago råder industrien over 45 pct., og 72 pct. af minekreditterne er koncentreret her.

Stillet over for denne realitet har regeringen indledt en demokratisering af kreditgivningen, hvis væsentligste mål er at give små og mellemstore landbrug og handelsforetagender adgang til kredit, samt bedre den geografiske ulighed. Til dette formål har man nedsat bankrenten og har påbegyndt statsopkøb af bankaktier samt fremsat lovforslag til fremme af processen.

\section{De regionale udviklingsplaner}

Koncentrationen af $\varnothing$ konomiske aktiviteter og befolkningen i hovedstadsprovinsen er resultatet af en lang historisk proces i den chilenske økonomi, og den er nu nået frem til at være en af de væsentligste hindringer for udviklingen. De 
historiske rødder til denne geografiske fordeling skal søges i den måde, hvorpå den chilenske $\varnothing$ konomi har været forbundet med den $\emptyset$ vrige verdens kapitalistiske system. Hovedstaden var det politiske og administrative centrum, hvorigennem overskuddene fra landets landbrugs- og mineproduktion flød. Disse penge flød i reglen enten ud af landet, eller også blev de brugt af det herskende borgerskab i forbindelse med dets krav til levestandard. Den kapitalistiske industriudvikling i tilbagestående og afhængige lande er centraliseret og ulige fordelt, og de samme mekanismer, der fører til hovedstadens monopolstilling, favoriserer en industriel koncentration i visse områder, mens de overlader resten af landet stillingen som forsyningsområde for råstoffer, fødevarer og arbejdskraft under de dårligst mulige betingelser.

I Chile blev industrialiseringen styret af dele af borgerskabet, der mere eller mindre direkte stod i forbindelse med internationale kapitalinteresser, og som lod sig lede af den snævre horisont, der begrænses af de private investeringers rentabilitet samtidig med, at de ofte benyttede sig af statsapparatet til egne formål og fordele. Den herved opståede industri centraliseredes alt for voldsomt i Santiago, der næsten blev det eneste virkeligt industrialiserede område i landet. I 1970 rummede Santiago nær ved 54 pct. af landets bybefolkning og næsten 37 pct. af den samlede befolkning. I 1967 skabtes 45 pct. af bruttonationalproduktet og 58 pct. af industriproduktionen i Santiago, og manufakturproduktionen fandt sted for 70 pct.'s vedkommende i de centrale provinser Valparaíso, Aconcagua, O’Higgins og Santiago. Den geografiske centralisering i de økonomiske aktiviteter modsvares af den ulige indkomstfordeling og den bureaukratiske administration. Centraladministrationen, finanssystemet og industrien er dannet omkring de geografiske uligheder i den $\varnothing$ konomiske struktur og støtter således disse. Eksempelvis var den 30. juni 197056 pct. af alle pengeanbringelser i private banker foretaget i Santiago. Disse banker, der opererer ud fra Santiago, kontrollerer næsten 87 pct. af alle pengeanbringelser i landet, og medtager man Statsbanken (der også ligger i Santiago), stiger tallet til 92 pct.

Men i Santiago finder man ikke blot centret for produktion og økonomiske og politiske beslutninger. Der findes tillige en enorm mængde fattige, der kom til denne by i søgen efter bedre levevilkår, og som blev indlemmet i bylivet i uproduktive beskæftigelser med lave indkomster. I det forløbne tiår er hovedstadsområdets andel af befolkningen vokset fra 49 pct. til 52 pct., skønt industriproduktionen i området har været konstant fra 1957-67.

Dette er i store træk den situation, hvori Folkefrontsregeringen overtog landet, og her ud fra vil den gå i planlægningen af den regionale udvikling.

Man må ikke opfatte anstrengelserne for regional udvikling som en korrigeret version af den traditionelle teori om polariseret udvikling. Folkefrontsregeringen er fast besluttet på at indlemme provinsernes underudnyttede ressourcer i det nationale 
$\varnothing$ konomiske liv i en sådan grad, at man opnår en total forandring af landets fysiognomi med hensyn til den geografiske fordeling af produktion og befolkning. Den selvmodsigende virkelighedsfortolkning, der fremkommer ved uhæmmet brug af begrebet »udviklingscenter «, og anvendelsen af politiske lapperier har ikke kunnet standse centraliseringsprocessen, der tværtimod er forløbet stadig hurtigere. Uden at foregive en kritisk analyse af den teori, der ligger bag udviklingscentrene som sikringer af decentralisering og regional udvikling, er det vigtigt at pege på nogle af dens selvmodsigelser, især hvad angår de private foretagenders og statens rolle. En udviklingspolitik for perifere og tilbagestående områder, der tager sit udgangspunkt i centerbegrebet, reserverer staten rollen som den, der forsyner de private foretagender med ressourcer gennem opbygning af infrastrukturen, gennem forsyning med udstyr og ved at påtage sig opgaver af en størrelsesorden og et risikomoment, de private foretagender ikke vil udsætte sig for. Denne reservation fører mod en dårlig udnyttelse af de producerede værdier og tjener kun til at styrke den gældende sociale struktur.

På trods af at denne politik betød en enorm ødslen med ressourcer, var dens virkning på den regionale udvikling minimal; den største del af erhvervslivet fandt fortsat hovedstaden geografisk fordelagtig, og strømmen af privat investering til provinsen kom aldrig i gang. Mine-enklaver som Chuquicamata og Salvador, salpeterlejerne og industri-enklaver som Concepción er typiske eksempler på en lokal udvikling, der er styret udefra, og som har meget lidt udviklende virkning på resten af provinsen. Den $\varnothing$ konomiske, sociale og kulturelle udvikling af alle egne af landet bliver ikke resultatet af »centrene«s virkning, men det nødvendige resultat af en klar og fast vilje til decentralisering og til skabelsen af $» \varnothing k o n o m i s k$ integrerede områder «.

Skønt der muligvis er blevet lagt for megen vægt på sociale og politiske argumenter for at prioritere integreringen af de chilenske provinser højt, er der en særdeles solid $\varnothing$ konomisk argumentation herfor: den ændring af produktionsstrukturen, som Folkefronten har foreslået, indebærer en udnyttelse af enorme $u$ udnyttede eller dårligt udnyttede ressourcer. En stor del af de reserver, der kan mobiliseres, findes ude i landet og ikke koncentreret i nogle få områder. Dette gælder f.eks. landbrugsjorden, mineralforekomsterne, skovene, fiskebestanden, o.s.v., og det gælder ligeledes arbejdskraften.

Planen for 1971 går i to retninger: en genoplivning af det regionale, $\varnothing$ konomiske liv og en mobilisering af det udbytte, hver enkelt region kan producere på kort sigt med den forhåndenværende mængde naturlige ressourcer, materiel og arbejdskraft. Man vil stræbe mod disse to kortsigtede mål ved generelt at stimulere al produktion, ved en generel højnelse af efterspørgslen, ved at støtte små og mellemstore producenter gennem en forøgelse af kreditmulighederne og gennem en forbedring af forhandlingen af og priserne på deres produkter og ved at anvende forskellige 
fremgangsmåder i forskellige regioner. I nogle regioner vil man mobilisere det potentielle udbytte gennem strukturelle og institutionelle ændringer, i andre gennem oprettelsen af produktionsoverenskomster, der ved at undgå de traditionelle handelskanaler vil kunne få en direkte virkning i retning af en omfordeling af indkomsterne. I visse regioner vil en statslig indgriben i standsede eller dårligt udnyttede produktioner tillade en højnelse af produktionen og skaffe muligheder for produktiv beskæftigelse ved at erstatte det private erhvervslivs rentabilitetskriterier med kriterier for social rentabilitet. Ydermere vil en nationalisering af de regionale monopolforetagender hurtigt hæve graden af udnyttelse af det forhåndenværende materiel og skabe områder, der kan være center for fremskridt og økonomisk udvikling, som det f.eks. er tilfældet med La Lanera Austral. I den nordlige zone vil nationaliseringen af mineressourcerne på kort sigt tillade en $\emptyset$ konomisk, social og kulturel integrering af arbejderne både i minerne og i resten af området.

Kort sagt: der findes for hver enkelt region en grundlæggende linie i mobiliseringsprogrammet, og denne modsvares af investeringer i produktion og socialforsorg, planer til en ny udnyttelse af de regionale ressourcer samt forskning i investeringer, administrationsformer og muligheder for folkets deltagelse i styret.

\section{Samlet vurdering af planen for 1971}

Såvel de sektorielle som de regionale planer, der her er skitseret, viser konkrete planer for og studier over, hvad regeringen agter at gøre for at igangsætte en kraftig offensiv til forøgelse af produktion og investering. De tilsigtede resultater er:

is Et stort spring fremad i aktivitetsniveau.

is En væsentlig nedskæring af arbejdsløsheden.

is En kraftig forøgelse af arbejdslønningerne.

is Særlige forholdsregler for at dække det chilenske folks behov for boliger, sundhedsvæsen, undervisning, ernæring, o.s.v.

tै Et nyt syn på de regionale problemer og herigennem en mere jæun og retfærdig udvikling for hver enkelt region med hensyn til udnyttelse af ressourcer og dækning af behov.

Alle disse projekter er inspireret af Folkefrontens program og falder inden for en opfattelse af den $\varnothing$ konomiske politik, der tildeler staten rollen som den faste og sammenhængende leder med klart definerede mål i retning af et socialistisk Chile.

Det er værd at resumere nogle globale aspekter ved planen: man vil skabe en kraftig stigning i reallønningerne gennem den skitserede lønjusteringspolitik og 
gennem en fastholdelse af prisniveauet; ikke-lønindkomster vil blive fastholdt nogenlunde på 1970-niveauet. Dette medfører, at en stor del af produktionsforøgelsen kommer lønindkomsterne til gode, især de laveste indkomster vil nyde godt af dette. Af andre aspekter kan nævnes en forøgelse af efterspørgslen gennem lønjusteringspolitikken; virkningen af mobiliseringsplanerne; støtten til ikke-monopoliserede foretagender (billig og demokratisk fordelt kredit, produktionsoverenskomster, o.s.v.); åbningen af nye markeder og en bedre brug af den eksisterende kapacitet, hvilket vil forårsage en betydelig forøgelse af industriproduktionen.

Der vil blive skabt væsentlige flere nye arbejdspladser end i tidligere år.

Lønarbejdernes andel af udbyttet bliver betydelig, og dette vil betyde en grundlæggende ændring af levestandarden for størstedelen af befolkningen.

Udvidelsen af den bestående og igangsættelsen af ny minedrift såvel som åbningen af nye eksport-markeder vil betyde et vigtigt skift $i$ handelsforbindelserne med udlandet.

En vigtig del af udbytteforøgelsen vil blive brugt til en hidtil uset højnelse af investeringerne, især i boliger.

Den $\varnothing$ konomiske reaktiviseringsproces vil desuden tillade en væsentlig for $\varnothing$ gelse af befolkningens forbrug.

Stigningen i nationalproduktet er baseret på en produktion af goder i form af varer i modsætning til tidligere, hvor den var koncentreret om tjenesteydelserne, og alligevel vil der blive lagt stor vægt på den sociale service, f.eks. inden for undervisning og sundhedsvæsen.

De sektorer, der ifølge denne plan udvides kraftigst, er de vareproducerende: minedrift, byggeri, industri, landbrug, energiproduktion og herefter de offentlige ydelser.

De programmer, der her er refereret til, deres forenelighed og især de strukturelle reformer, man agter at gennemføre, viser, at den revolutionære proces, regeringen har sat i gang, vil blive fulgt af en større vækst, end man har set i de sidste år. Det vigtigste grundlag for den udvikling, der er indeholdt i 1971-planen, er folkets organiserede deltagelse, og det vil på samme tid være det store flertal af befolkningen, der kommer til at nyde godt af dens gennemførelse. En af de største vanskeligheder for gennemførelsen af planen er manglerne i det eksisterende bureaukratisk-administrative apparat. Den chilenske central-administration var faktisk ikke forberedt på at opfylde de krav, en angribende og aktiviserende plan stiller. Vi hentyder her ikke blot til de alvorlige strukturelle problemer, men også til den mentalitet, der behersker mange funktionærer. Planens gennemf $\varnothing$ relse kræver ikke blot sikre investeringer og finansieringer, men også en kraftig anstrengelse for at rette de nævnte mangler. Planen indeholder initiativer, som vil være til gode for alle arbejdere og for en stor del af landets middelklasse, som vil se en dæmpning i prisstigningerne, en forbedring af deres reelle købekraft, en 
udvidelse af undervisning og sundhedsvæsen, samt lettere adgang til at få eget hus. De ikke-monopoliserede foretagender står over for en stor opgave i denne samlede, nationale kraftanstrengelse, og de vil komme til at nyde godt af et større marked, bedre kredit og muligheden for en fri og direkte dialog med regeringsorganerne og med repræsentanter for arbejderne.

1971-planen, som omfatter en detaljeret operationsplan for den offentlige sektor, er et systematisk og organiseret forsøg på at drage Chile ud af stagnationen, og den tilbyder folket mulighed for at deltage i udarbejdelsen og i den praktiske gennemførelse. Kun på denne måde kan det lykkes at overvinde de vanskeligheder, der traditionelt har forhindret landet $\mathrm{i}$ at nå en udviklingsrytme i overensstemmelse med befolkningens potentielle muligheder og de nationale ressourcer. 